
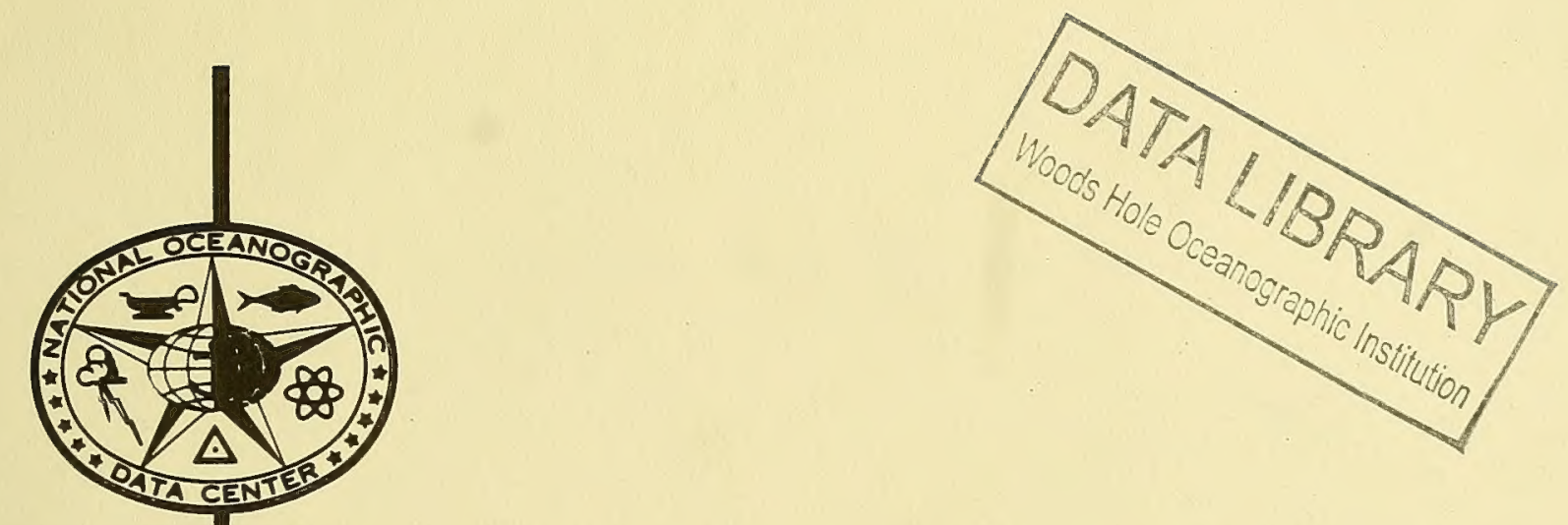

\title{
NATIONAL OCEANOGRAPHIC DATA CENTER
}

MANUAL SERIES

\section{MANUAL FOR PROCESSING CURRENT DATA}

\author{
PART I \\ INSTRUCTIONS FOR CODING AND KEYPUNCHING. \\ DRIFT BOTTLE DATA
}

GC

235

.93

1964

2 Dirconte Fla - SHM 

NATIONAL OCEANOGRAPHIC DATA CENTHER

MANUAL SERTES

MANUAL FOR PROCESSING

CURRENT DATA

PART I

INSTRUCTIONS FOR CODING AND KEYPUNCHING DRIFT BOTPLE DATA

$$
\text { PUBLICATION M - } 6
$$

(PROVISIONAL)

1964

Reprinted by

U.S. DEPARTMENT OF COMMERCE

National Oceanic and Atmospheric Administration

1972

Copies of this document are obtainable from the National Technical Information Service (NTIS), Springfield, Va. 22151. 
During the December 1963 meeting of the Committee for the Scientific Exploration of the Atlantic Shelf (SEAS), 1t was suggested that a storage and retrieval system for Drift Bottle Data be set up at the National Oceanographic Data Center (NODC). The suggestion received the full support of the SEAS Cormittee.

For the past several months, personnel at the NODC, under the guidance of Dean Bumpus of Woods Hole Oceanographic Institution and John Norcross of the Virginia Inst1tute of Marine Sclence, have developed a provisional system for the storage and retrieval of drift bottle data.

This provisional publication provides instructions for reporting reduced release and release-recovery drift bottle data either on the NODC coding form or punch card.

Th1s Center welcomes comments and suggest1ons regarding this provlsional system as well as the recelpt of drift bottle data prepared utilizing the NODC coding forms or NODC punch card. Reduced drift bottle data reported on other formats are acceptable if the data and units are compatible with those of this system.

W. C. JACOBS

Director

National Oceanograph1c Data Center 
FOREWORD .......................... $\mathrm{ii}$

INTRODUCTION ............................. 1

GENERAL ......................... 2

CODING THE RELEASE INFORMATION . . . . . . . . . . 4

CODING THE RELEASE-RECOVERY INFORMATION . . . . . . 7

KEYPUNCHING INSTRUCTIONS FOR THE DRIFT BOTTLE

CODING FORM . . . . . . . . . . . . . . . 11

APPENDIX I - DRIFT BOTTLE CODING FORM (PROVISIONAL) . . . 18

\section{LIST OF TABLES}

TABLE I. COUNTRY CODE ................. . . 13

TABLE II. INSTITUTION CODE . . . . . . . . . . 14

TABLE III. MODE OF RELEASE CODE . . . . . . . . . . 16

TABLE IV. BOTTLE TYPE CODE . . . . . . . . . . . . 17 

This manual provides instructions for coding and keypunching drift bottle data on a standard format. In these instructions, the term "drift bottle" includes ballasted and unballasted drift bottles, sea bed drifters, drift cards, and similar devices. The term does not Include monitored drifting devices such as swallow Floats.

The provisional Drift Bottle Coding Form (Appendix I) is designed to accommodate both release data and release-recovery data. If used for reporting release data only, the portion of the coding form labeled RECOVERY INFORMATION is left blank. If used for reporting releaserecovery data, both the recovery information and the original release data must be entered on the coding form.

The card used by the NODC in this system is the standard 80-column punch card. A single format card is used to record both the release and release-recovery data.

Drift bottle data w1II be available from the NODC on magnet1c tape, punch cards, or as Iistings. Both the release data and the releaserecovery data for each type of bottle are sorted geographically on the release position in the following sequence: Marsden square, 1-degree square, 1/4-degree square, year, month, day, institution, and ship (platform). By special request, these data may also be obtained sorted geographically on recovery position. 


\section{GENERAI}

In most 1nstances, the fields of the coding form and punch card labeled Bearing, Nautical Miles Drifted, Days Adrift, and Speed may, at the option of the origlnator, be left blank. If values for these fields are not reported, they will be computed at the NODC. However, when the straight line between release point and recovery point passes over land, the originator must determine and code Bearing, Naut1cal Miles Drifted, Days Adrift, and Speed (Columns 63-75). The definitions of these terms, as related to the system, are as follows:

Bearing - The direction of a straight Ilne drawn (on Mercator projection) from the release position to the recovery position, expressed as an angular distance from $000^{\circ}$ clockwise through $360^{\circ}$.

Nautical Miles Drifted - The straight line distance, in nautical mlles, between the release and recovery positions. (Th1s distance may or may not represent the actual distance traveled by the bottle; $1 t$ does, however, provide a "distance" value for the computation of speed.)

Days Adrift - The time elapsed (usually in whole days) between the time of release and the time of recovery of a bottle. (This time entry may or may not represent the actual travel time between release and recovery positions; 1t does, however, provide a time value for the computation of speed.)

Speed - The value obtained by dividing the entry for "Nautical Miles Drifted" by the entry for "Days Adrift." The speed thus computed may or may not be related to the actual speed of the bott]e. 
Release data from a lightship which routinely makes dally releases may be coded as a single release report for the entire month. In this case, asterisks are entered in the DAY field (Columns 20-21), and the entry in the NUMBER OF BOTMLES RELEASED field (Columns 39-40) represents the total number of bottles released for the month.

Releases of different bottle types at the same location and at the same time constitute separate releases and must be recorded as such on the coding form. 
Enter the Cruise and/or Project Humber, the complete name of the institution sponsoring the research, and the name of the platform from which the bottles were released, in the space provided in the upper right corner of the coding form.

Columns 1-7

NODC REFERENCE NUMBER AND CONSECUTIVE NUMBER

Leave blank. These columns w1ll be coded at the NODC.

Columns $8-9$

COUNTRY CODE

Enter the country code as given in Table I.

Columns 10-11

INSTTIUTION CODE

Enter the institution code as given in Table II. The institution code should reflect the institution sponsoring the research.

Column 12

MODE OF RETEASE

Enter the mole of release code as given in Table III.

Columns 13-15

SHIP CODE

Leave blank. These columns w1Il be coded at the NODC.

Columns 16-17

YEAR

Enter tens and units digits of year.

Columns 18-19

MONTH

Enter the month by using the mumerals 01 (January) through 12 (December). 
Enter the day of month by using the numerals 01 through 31 . When day of release is doubtful, leave blank.

Columns 22-23

TDME

Enter local standard time of release to nearest hour by using the numerals 00 through 24.

Columns 24-32

IATITUDE AND IONGITUDE OF RETEASE

Enter degrees and whole minutes of lat1tude and longitude in Columns 24-27 and 28-32, respectively. Enter $\underline{N}$ or $\underline{S}$ for northern or southern hemisphere, and $E$ or $W$ for eastern or western hemisphere, in the space provided following Columns 27 and 32 , respectively.

Columns $33-36$ REIFASE MARSDEN SQUARE AND $1 / 4^{\circ}$ SQUARE

Ireave blank. This information will be computed and punched'into the card at the NODC.

Columns $37-38$

DISTANCE FROM SHORE

Enter the shortest distance from the release position to shore in whole nautical miles. Enter numerals 99 in these columns to indicate that the distance from shore is 99 nautical miles or greater. If stations are relatively close to shore, distance may be reported to tenths of a nautical mile by entering the tenths digit in Column 38 ; enter a red dash over the tenths numeral in Column 38. Prefix a zero to fill the fleld when necessary. 
Enter the number of bottles for each bottle type released at the time recorded in Columns 22-23. Prefix a zero to 1111 the field.

Column 41

BOTPLE TYPE

Enter the bottle type according to the code in Table IV.

Column 76

CARD TYPE

Enter the numeral I in Column 76 .

Columns $77-78$

Columns 77-78 are left blank on the coding form.

Columns $79-80$

DECK NUMBER

No entry is required on the coling form; however, the numeral 10 must be entered in these columns of the punch card. 
Enter the Crulse and/or Project Number, the complete name of the institution sponsoring the research, and the name of the platform from which the bottles were released, in the space provided in the upper right corner of the coding form.

Columns $1-7$

\section{NODC REFERENCE NUMBER AND CONSECUTIVE NUMBFR}

Legve blank. These columns will be coded at the NODC.

Columns 8-41

REIEASE INIFORMATION

When release-recovery data are reported, the origlnal release Information for the recovered bottle must be Included. Code these columns as previously instructed.

Columns $42-46$

BOTTLEE NUMBFR

Enter the 1dentification number of the recovered bottle. Prefix zeros to fill the field.

Columns $47-48$ YEAR

Enter tens and unfts diglts of year of recovery.

Columns 49-50

MONTH

Enter the month by using the numerals ol (January) through 12 (December). If month of recovery is considered to be doubtful, enter a red dash over the numeral in Column 49.

Columns 51-52

DAY

Enter the day of month by using the numerals 01 through $3 I$. If day of recovery is considered to be doubtful, enter a red dash over the numeral in Column 51. 
Enter degrees and whole minutes of latitude and longltude in Columns 53-56 and 57-61, respectively. Enter $\underline{N}$ or $\underline{S}$ for northern or southerm hemisphere, and $\mathrm{E}$ or $\mathrm{W}$ for eastern or western hemisphere, in the space provided following Columns 56 and 61, respectively. If the position is doubtful, estimate the latitude and/or longitude to the nearest 10 minutes; enter the tens dig1t in Columns 55 and/or 60, and leave Columns 56 and 61 blank.

Column 62 WHERE RECOVERED

Indicate where the bottle was recovered by entering the letter A for ashore, $\underline{B}$ for bottom, $\underline{F}$ for floating, or $\underline{E}$ when in an estuary.

Columns 63-65

BEARING

Enter the direction in degrees (measured clockwise from $000^{\circ}$ ) of a line drawn (on Mercator projection) from the release position to the recovery position. If, in the opinion of the originator, the route of the drift bottle was clrcuitous, enter the letters CIR in Colums 63-65. If the recovery position is in an estuary (E In Column 62), the bearing reported should represent the direction of a line drawn from the release position to the point of turning Into the estuary. 
Enter the straight Ilne distance (in whole nautical miles) between the release and recovery positions so that the unft digit 1s entered 1n Column 69. Distance may be reported to tenths of a nautical mile by entering the tenths digit in Column 69 and a red dash over the tenths dig1t. If the letter $E$ appears in Column 62 or the letters $C I R$ appear in Columns 63-65, inferred distances rather than straight-Ine distances should be coded.

Columns $70-72$

DAYS ADRIFT

Enter the number of days from date of release to date of recovery In whole days so that the unfts digit is entered in Column 72 . If number of days adrift is greater than 999, enter the thousands, hundreds, and tens digits in Column $70-72$ and a red dash over the numeral in Column 70. Prefix zeros to fill the fleld. Time adrift may be reported In hours and tenths of an hour; enter the whole hours in Columns 70 and 71 and the tenths digit in Column 72 . When hours are reported, enter a red dash in Column 72. Prefix zeros to 111 the field. Do not enter a zero in Column 72 if tenths are not reported.

Columns $73-75$

SPEEED

Enter the speed in nautical miles per day to tenths of a nautical mile. Preflx zeros to fill the fleld. Speed in knots to tenth of a knot may be reported by entering whole knots in Columns 73 and 74 and the tenths digit in Column 75. If knots are reported, enter a red dash in Column 75. Do not enter a zero in Column 75 if tenths are not reported. 
Enter the numeral $\cong$ in Column 76 .

Columns $77-78$

Columns 77-78 are left blank on the coding form.

Columns 79-80

DECK NUNBER

No entry 1 s required on the coding form; however, the numeral 10 must be entered in these columns of the punch card. 
The Drift Bottle Coding Form is designed so that most of the numeric and alphabetic entries can be punched directly into the corresponding columns of the punch card. The correct column entries for certain overpunches, however, may not be readily determined from the coding form. A red dash, entered in a specific column of the coding form, generally Indicates that the same column on the punch card should recelve an $x$ (or eleven) overpunch.

Entries on the coding form which require $x$ overpunches on the punch card are as follows:

Entry on Coding Form

S after Column 27

E after Column 32

Red dash in Column 38
Explanation

South lat1tude

East longltude

Distance from shore reported to tenths of a nautical mile

Red dash in Column 49 Recovery month doubtful

Red dash in Column 51 Recovery day doubtful

S after Column 56

E after Column 61

Red dash In Column 69

Red dash in Column 70

Red dash In Column 72

Red dash in Column 75

\section{South lat1tude}

Fast Iong1tude

Nautical miles drifted reported to tenths of a neutical mile

Days adrift over 999

Hours adrift

Speed in knots
Entry on Punch Card

$x$ overpunch Column 27 x overpunch Column 32 x overpunch Column 38

x overpunch Column 49 $\underline{x}$ overpunch Column 51 x overpunch Column 56 x overpunch Column 61 $\underline{x}$ overpunch Column 69 x overpunch Column 70 $\underline{x}$ overpunch Column 72 x overpunch Column 75 
When one or several of the 1tems contalned in Columns 66-75

(bearing, nautical miles drifted, days adrift, and speed) are omitted, the Information for all these items will be computed at the NODC. To 1dentify these NODC-computed values, an $x$ overpunch, generated by the computer, is automatically entered in Column 78 of the release-recovery $\operatorname{card}$. 


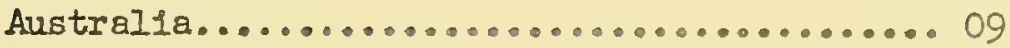

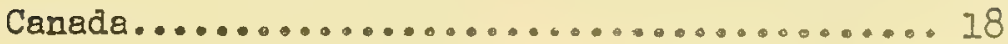

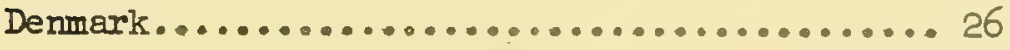

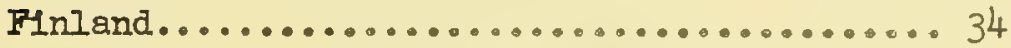

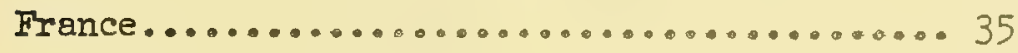

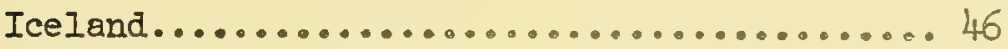

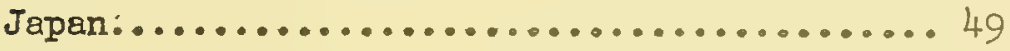

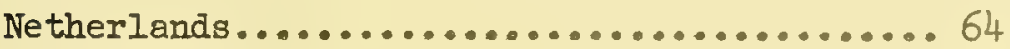

New Zealand..........................61

Union of South Africa.................. 91

Union of Soviet Soc1al1sts Republics........ 90

United States of America................ 31

I/Th1s table w1Il be expanded as the need arises. 
Bingham Oceanograph1c Laboratory, Yale Univers1ty................. 18 California State Department of F1sh and Game, Marine Resources

Branch............................................. 17

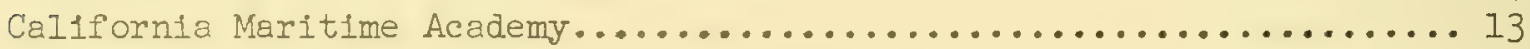

Chesapeake Bay Institute, The Johns Hopkins UnIversity............ 21

Chesapeake B1ological Laboratory, University of Maryland........... 52

Columb1a University, Hudson Laboratories........................ 26

Columb1a University, Lamont Geological Observatory................ 12

Duke University, Marine Laboratory............................ 55

Florida State Board of Conservation, Marine Laboratory............ 57

Gulf Coast Research Laboratory............................. 32

Hancock Foundation, University of Southern Cal1fornia............. 19

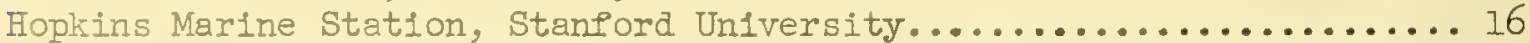

Hudson Laboratorles, Columb1a Un1versity...................... 26

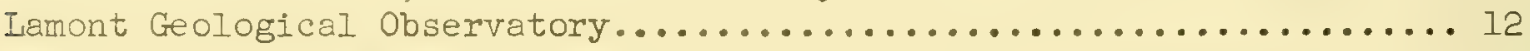

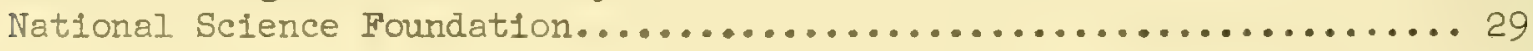

Narragansett Marine Laboratory, Un1versity of Rhode Island......... 30

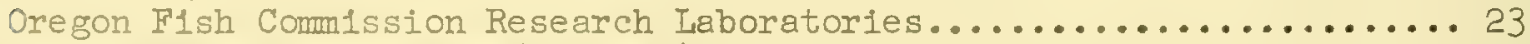

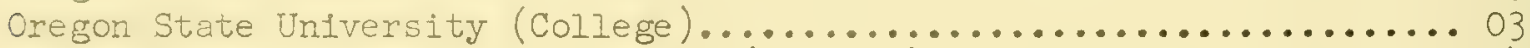

Paciflc Marine Station, University (College) of the Pacific......... 14

Scripps Institution of Oceanography, Unlversity of California

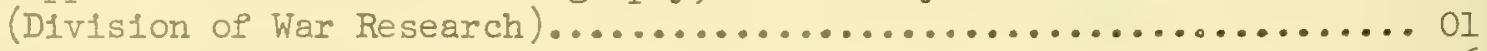

Stanford University, Hopkins Marine Station.................... 16

State University of New York, Marit1me College.................... 27

Texas A \& M University, Department of Oceanography and Meteorology.... 24

The Johns Hopkins University, Chesapeake Bay Inst1tute............ 21

University of California, Scripps Institution of Oceanography........ 01

University of Florida, Marine Laboratory........................ 06

Unlversity of Maryland, Chesapeake Blological Laboratory............ 52

University of Miam1, Institute of Marine Sciences................. 25

University of Rhode Island, Narragansett Marine Laboratory.......... 30

Un1versity of Southern California, Hancock Foundation............. 19

University of the Pacif1c, Pacific Marine Stat1on................. 14

University of Washington, Department of Oceanography............. 09

U. S. Coast and Geodetic Survey............................. 10

U. S. Coast Guard...................................... 06

U. S. Department of the Interior, Flsh and W1ldilfe Service......... 11

Bureau of Commercial Fisher1es, B1olog1cal Laboratories

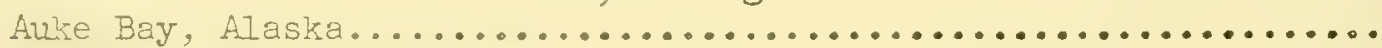

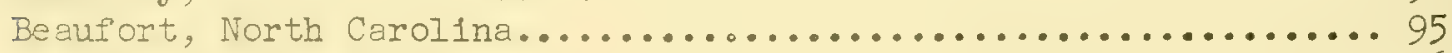

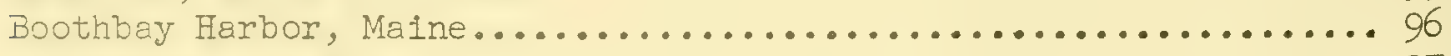

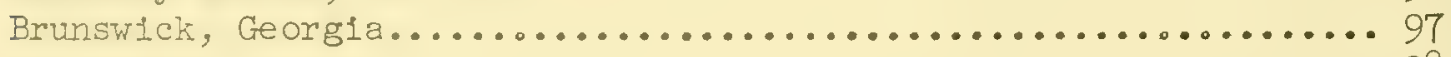

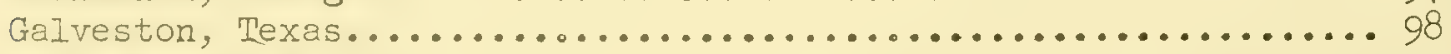

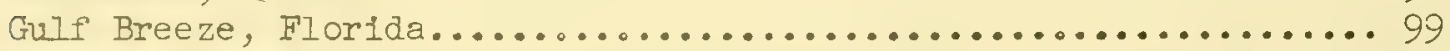

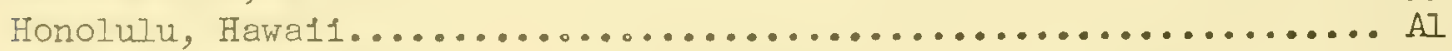

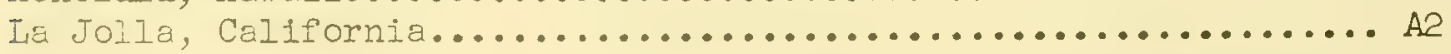


U. S. Department of the Interfor, Fish and Wildife Service Bureau of Commercial Flsheries, Blological Laboratorles (Cont'd)

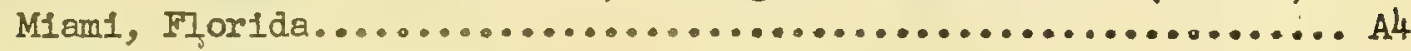

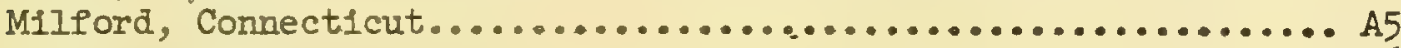

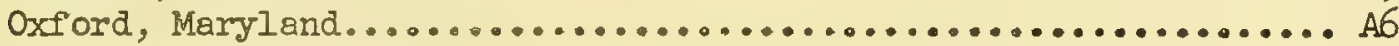

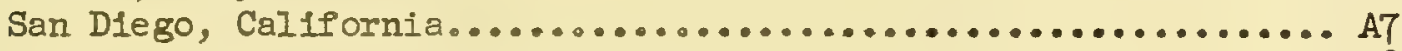

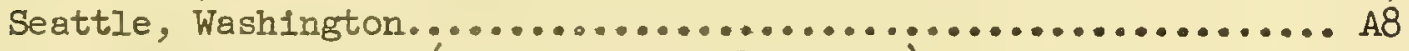

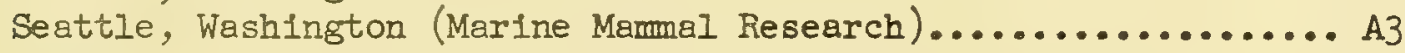

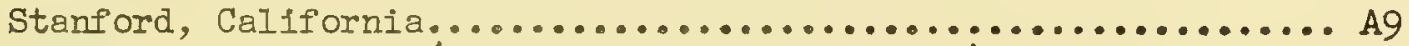
Tiburon, California (Tiburon Marıne Laboratory)............... 31

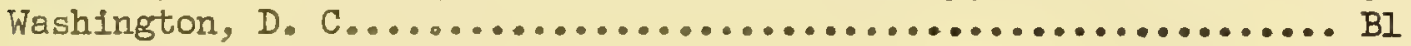

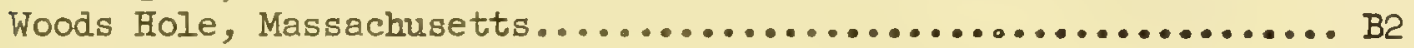
Bureau of Sport Fisheries

Sandy Hook Marine Laboratory............................. B4 U. S. Naval Oceanographic Office (NAVOCEANO) .................... OT U. S. Naval Ordnance Laboratory (NOL) . . . . . . . . . . . . . . . . . ... 22 U. S. Naval Underwater Ordnance Station (NUOS) .................. 15 U. S. Naval Underwater Sound Laboratory (USNUSL)................. 08 U. S. Navy Electronics Laboratory (NEL) . . . . . . . . . . . . . . . . . . 20 U. S. Navy, Sclentific................................ 04 U. S. Navy, Sh1ps of Opportunity........................... 05 Virginia Institute of Marine Science......................... 28 Woods Hole Oceanographic Inst1tut1on (WHOI) ..................... 02 Yale University, B1ngham Oceanographic Laboratory................ 18 


\section{MODE OF RETEASE CODE}

Mode

Code

Surface........................... I

Aer1al............................. 2

Subsurface......................... 3

Shore............................ 4 
TABTI

BOTILE TYPE CODE

Bottle Type

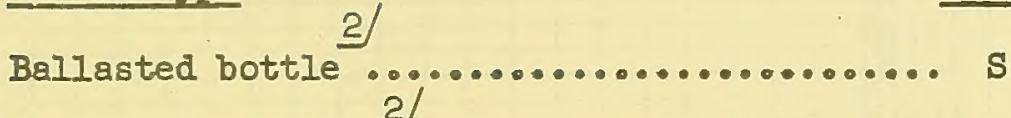

Unballasted Bottle .................. N

Sea bed drifter....................... B

Drift card (or envelope)............... C

Drogue bottle....................... D

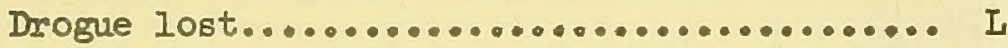

If This table will be expanded as the need arlses.

$2 /$

Bottles floating at an angle equal to or greater than 45 degrees from the horlzontal position are designated as "ballasted;" bottles floating at an angle less than 45 degrees from the horlzontal position are designated as "unballasted." 


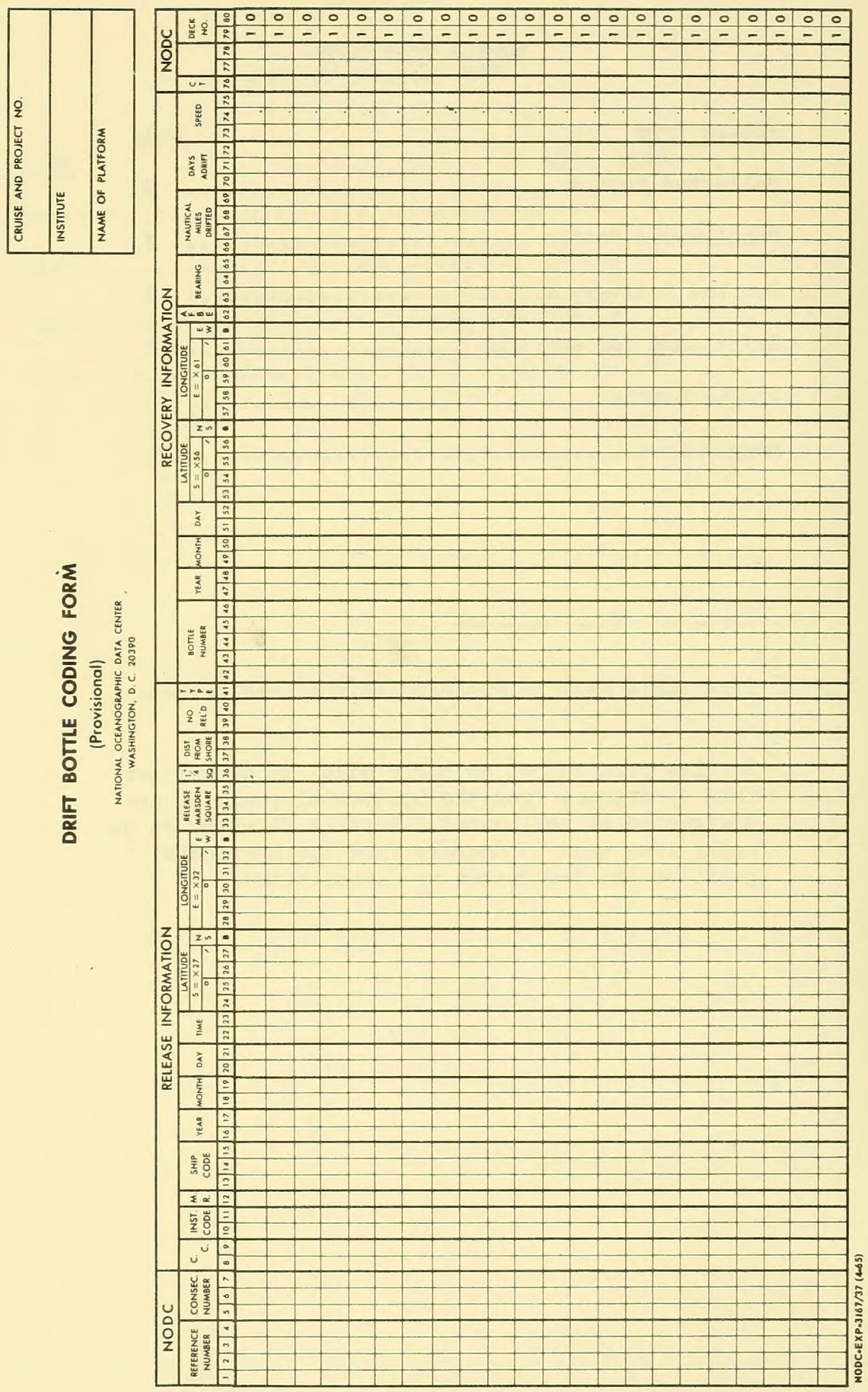


